\title{
GABAergic Neurogliaform Cells Represent Local Sources of Insulin in the Cerebral Cortex
}

\author{
Gábor Molnár, ${ }^{1 \star}$ Nóra Faragó, ${ }^{2 \star}$ Ágnes K. Kocsis, ${ }^{1 \star}$ Márton Rózsa, ${ }^{1}$ Sándor Lovas, ${ }^{1}$ Eszter Boldog, ${ }^{1}$ Rita Báldi, ${ }^{1}$ \\ Éva Csajbók, ${ }^{3}$ János Gardi, ${ }^{3}$ László G. Puskás, ${ }^{2,4}$ and Gábor Tamás ${ }^{1}$ \\ ${ }^{1}$ Research Group for Cortical Microcircuits of the Hungarian Academy of Sciences, Department of Physiology, Anatomy and Neuroscience, University of \\ Szeged, Szeged, H-6726, Hungary, ${ }^{2}$ Laboratory of Functional Genomics, Department of Genetics, Biological Research Center, Hungarian Academy of \\ Sciences, Szeged, H-6726, Hungary, ${ }^{3}$ Endocrinology Unit, First Department of Internal Medicine, University of Szeged, Szeged, H-6720, Hungary, and \\ ${ }^{4}$ Avidin Ltd, Szeged, H-6726, Hungary
}

Concentrations of insulin in the brain are severalfold higher than blood plasma levels. Insulin in the brain regulates the metabolism, molecular composition, and cognitive performance of microcircuits and reduces food intake; cerebral insulin levels are altered in diabetes, aging, obesity, and Alzheimer's disease. Released by pancreatic $\beta$ cells, insulin passes the blood-brain barrier, but sources of locally released insulin still remain unclear. We find that insulin is strongly expressed in GABAergic neurogliaform cells in the cerebral cortex of the rat detected by single-cell digital PCR. Focal application of glucose or glibenclamide to neurogliaform cells mimics the excitation suppressing effect of external insulin on local microcircuits via insulin receptors. Thus, neurogliaform cells might link GABAergic and insulinergic action in cortical microcircuits.

\section{Introduction}

Insulin is present in the CNS in concentrations of 10-100 times higher than plasma levels, depending on the area of the brain (Havrankova et al., 1978b). Insulin regulates the metabolism, molecular composition, and cognitive performance of microcircuits (Wan et al., 1997; Beattie et al., 2000) with specific alterations in diabetes, aging, obesity, and Alzheimer's disease (Gasparini et al., 2002; Porte et al., 2005). Since this first report suggesting the presence of both pancreatic and locally synthesized insulin in the brain (Havrankova et al., 1978b), a multitude of studies argued in favor of peripheral and central sources. Insulin can cross the blood-brain barrier as shown by increased insulin levels in the cerebrospinal fluid (CSF) after infusion of insulin in the periphery (Margolis and Altszuler, 1967) and studies finding correlation between steady-state endogenous insulin levels in the plasma and CSF (Woods and Porte, 1977), suggesting that insulin enters CNS through the blood-brain barrier by a saturable transport system (Banks et al., 1997). However, local insulin synthesis in the CNS was suggested by variable brain versus blood insulin ratios in experimental paradigms and in pathological states

Received Sept. 24, 2013; revised Dec. 2, 2013; accepted Dec. 10, 2013.

Author contributions: É.C., L.G.P., and G.T. designed research; G.M., N.F., Á.K.K., M.R., S.L., E.B., R.B., É.C., J.G., L.G.P., and G.T. performed research; G.M., N.F., A.K.K., M.R., S.L., E.B., R.B., É.C., J.G., L.G.P., and G.T. analyzed data; G.M., L.G.P., and G.T. wrote the paper.

We thank B. Lambolez, B. Cauli, and J. Rossier for training G.T. in harvesting cytoplasms of neurons; L. Schäffer for donating S961; and E. Tóth for reconstructions.

The authors declare no competing financial interests.

*G.M., N.F., and Á.K.K. contributed equally to this work.

Correspondence should be addressed to Dr. Gábor Tamás, Research Group for Cortical Microcircuits of the Hungarian Academy of Sciences, Department of Physiology, Anatomy and Neuroscience, University of Szeged, Közép fasor 52, Szeged, H-6726, Hungary. E-mail: gtamas@bio.u-szeged.hu.

DOI:10.1523/JNEUROSCI.4082-13.2014

Copyright $\odot 2014$ the authors $\quad 0270-6474 / 14 / 341133-05 \$ 15.00 / 0$
(Havrankova et al., 1979; Baskin et al., 1985; Gasparini et al., 2002; Pilcher, 2006) and by in situ hybridization and immunocytochemical studies detecting insulin mRNA in developing and adult neurons and neuronal progenitor cells (Dorn et al., 1983; Devaskar et al., 1994; Kuwabara et al., 2011; Mehran et al., 2012), but the identity of neurons expressing insulin in terms of functional cell classes is not clear. We determined the number of insulin mRNAs in various cell classes in the cerebral cortex and tested whether insulin can be released in the local microcircuit.

\section{Materials and Methods}

Electrophysiology and imaging. All procedures were performed with the approval of the University of Szeged and in accordance with the National Institutes of Health Guide for the Care and Use of Laboratory Animals. Male Wistar rats (P22-P35) were anesthetized by intraperitoneal injection of ketamine $(30 \mathrm{mg} / \mathrm{kg})$ and xylazine $(10 \mathrm{mg} / \mathrm{kg})$; and after decapitation, coronal slices $(350 \mu \mathrm{m})$ were prepared from the somatosensory cortex. Slice preparation and recordings were performed as described previously (Oláh et al., 2009). Micropipettes (5-7 M $\Omega$ ) were filled with (in mM) the following: $126 \mathrm{~K}$-gluconate, $4 \mathrm{KCl}, 4 \mathrm{ATP}-\mathrm{Mg}$, $0.3 \mathrm{GTP}-\mathrm{Na}_{2}$, 10 HEPES, 10 creatine phosphate, and 8 biocytin ( $\mathrm{pH} 7.25 ; 300 \mathrm{mOsm}$ ); in low extracellular glucose concentrations, the intracellular solution did not contain ATP-Mg, GTP- $\mathrm{Na}_{2}$, and creatine phosphate. Signals were filtered at $5 \mathrm{kHz}$, digitized at $10 \mathrm{kHz}$, and analyzed with PULSE software (HEKA). Voltage-clamp protocols were applied according to Zawar et al. (1999). Detection of spontaneous EPSCs was performed with NeuroMatic functions for Igor Pro (Wavemetrics). In our low chloride recording conditions, reversal potential of unitary inhibitory postsynaptic potential was $-73.3 \pm 3 \mathrm{mV}$; thus, separation of GABAergic currents was based on polarity. After Gaussian filtering, EPSC events were detected with threshold detection algorithm and events were reviewed after automatic detection. Threshold was set to $3 \mathrm{pA}$, onset time limit was set to 2 $\mathrm{ms}$, which defines the maximum interval from the baseline to the deflection reaches the threshold. Peak time limit was set to $3 \mathrm{~ms}$. For imaging, neurogliaform cells were filled with $10 \mu \mathrm{M}$ Alexa594 and $120 \mu \mathrm{M}$ OGB-1 
(Invitrogen) added to the ATP-free intracellular solution with the application of the hypoglycemic extracellular solution, and detection of signals was performed with a Revolution XD system and IQ Software (Andor). Data are presented as mean $\pm \mathrm{SD}$ throughout, $n$ values refer to the number of neurons, and statistical tests are defined for each paradigm.

Histology. Visualization of biocytin and correlated light microscopy and electron microscopy was performed as described previously (Oláh et al., 2009). Three-dimensional light microscopic reconstructions were performed using Neurolucida (MicroBrightfield) with $100 \times$ objective.

Single-cell harvesting. At the end of electrophysiological recordings, the intracellular content was aspirated into the recording pipette by application of a gentle negative pressure while maintaining the tight seal. The pipette was then delicately removed to allow outside-out patch formation, and the content of the pipette $(2 \mu \mathrm{l})$ was expelled into a low-adsorption test tube (Axygen). Sample was snap-frozen in liquid nitrogen and stored or immediately used for RT.

First-strand cDNA synthesis. RT was performed in two steps. The first step was done for $5 \mathrm{~min}$ at $65^{\circ} \mathrm{C}$ in a total reaction volume of $5 \mu \mathrm{l}$, containing $2 \mu \mathrm{l}$ intracellular solution with the cytoplasmic content of the neuron, $0.3 \mu \mathrm{l}$ reverse primer (Bioneer), $0.3 \mu \mathrm{l} 10 \mathrm{~mm}$ dNTPs (Invitrogen), $1 \mu \mathrm{l} 5 \times$ first-strand buffer, $0.3 \mu \mathrm{l}$ of $0.1 \mathrm{~mol} / \mathrm{L}$ DTT, $0.3 \mu \mathrm{l}$ of RNase inhibitor (Invitrogen), and $100 \mathrm{U}$ of reverse transcriptase (Superscript III; Invitrogen). RT primers were designed using CLC Main Workbench (CLC Bio) software, and the sequences were the following: $r p s 18: 5^{\prime}$-ATTAACAGCAAAGG CCCA-3'; ins2: 5' -TTTATTCATTGCAGAGG GG-3'. The second step of the reaction was performed at $50^{\circ} \mathrm{C}$ for $1 \mathrm{~h}$, and then the reaction was stopped by heating at $70^{\circ} \mathrm{C}$ for $15 \mathrm{~min}$. The RT reaction mix was used in PCR amplification.

Single-cell $q R T-P C R$. Reactions were performed after preamplification of cDNA in a total volume of $20 \mu \mathrm{l}(5 \mu \mathrm{l}$ RT product, $1 \mu \mathrm{l}$ of TaqMan primer; rps18: Rn01428913_gH; ins2: Rn01774648_g1), $10 \mu$ l TaqMan PreAmp Master Mix (Invitrogen), and $4.5 \mu \mathrm{l}$ nuclease-free water in MyGenie 32 Thermal Block (Bioneer) using protocols as described previously (Faragó et al., 2013). We repeated qRT-PCRs (traditional and digital) amplifying both the control gene rps18 and ins2 without reverse transcriptase reaction and found no amplification and no PCR products, meaning that possible genomic DNA amplification background under our conditions was negligible. To further eliminate the possibility of amplifying genomic DNA, we tried to amplify the read-through of ins2igf2 mRNA transcript and also multiple introns of the ins2 as well as intergenic region at the ifngr 1 gene locus on chromosome 1 , and neither of these primer sets gave positive results during QRT-PCR.

Sequencing. We sequenced 4 individual PCR products from 4 individual neurogliaform cells using capillary electrophoresis sequencing on 3500 Genetic Analyzer (Invitrogen). After purification of the products, we used 4 different sequencing primers using the following primer sequences: forward 1, 5' -5'-cccatgtccegccgcg-3' (16); forward 2, 5' gtggaggacccacaagtg-3' (18); reverse 1, 5' -tgccaaggtctgaaggtcac- $3^{\prime}$ (20); reverse $2,5^{\prime}$-ttctgccgggccacctcc-3' (18).

Digital PCR. For digital PCR analysis, in case of rps18 $2.5 \mu$ l RT mixture or in case of ins $25 \mu \mathrm{l}$ RT reaction mixture, $2 \mu \mathrm{l}$ TaqMan assays, $10 \mu \mathrm{l}$ OpenArray Digital PCR Master Mix (Invitrogen), and nuclease free water $(2-4.5 \mu \mathrm{l})$ were mixed in a total volume of $20 \mu \mathrm{l}$. The mixture was distributed on an OpenArray plate, cycled on an OpenArray NT cycler, and analyzed using the Biotrove OpenArray Digital PCR Software (version 1.0). as described previously (Faragó et al., 2013). For our dPCR protocol amplification, reactions with $C_{T}$ confidence values $<100$ as well as reactions having $C_{T}$ values $<23$ and $>33$ were considered primer dimers or background signals, respectively, and excluded from the dataset.

Radioimmunoassay. Insulin extraction of cells was performed in the cold by the acid-ethanol technique. Radioimmunoassay (Sensitive Rat Insulin RIA kit, Millipore) was used to determine insulin contents with a sensitivity of $2 \mathrm{pg} /$ tube. BCA protein assay kit (Pierce) was used for detecting total protein content.

\section{Results}

We tested whether different neocortical neuron types, all of them identified by whole-cell recordings and subsequent light microscopic assessment (Fig. 1A), express the mRNA of the ins 2 gene encoding preproinsulin in the rat (Twigger et al., 2007). After electrophysiological and anatomical identification of cell types based on characterization of membrane and firing properties (Fig. 1A), we harvested the cytoplasm of the recorded cells and applied conventional single-cell qRT-PCR with preamplification protocol and detected ins 2 mRNA in 15 of 19 neurogliaform cells (Fig. 1C). To exclude any possibilities in amplifying DNA fragments other than ins2, we sequenced four individual PCR products from $n=4$ neurogliaform cells and found 100\% match ( 84 of $84 ; 47$ of $47 ; 42$ of $42 ; 31$ of 31 ) to the ref|NM_019130.2| Rattus norvegicus insulin 2 (ins2) mRNA sequence. To determine the number of ins 2 mRNA molecules present in the harvested peri- 
somatic cytoplasm of these cell types, we adapted the digital PCR method to single neurons without preamplification steps, which would have decreased reliability (Faragó et al., 2013) (Fig. 1C). In high extracellular glucose concentration $(10 \mathrm{~mm})$, which is standard for brain slice electrophysiology experiments, individual neurogliaform cells $(n=10)$ contained higher numbers of ins2 mRNAs $(30 \pm 13)$ compared with pyramidal $(7 \pm 2, n=6)$ and fast spiking cells ( $5 \pm 3, n=5, p<0.002$, Kruskal-Wallis test). As a functional control, we lowered the glucose concentration to levels close to what was found in the brain during normoglycemia $(2.4 \mathrm{~mm})$ and hypoglycemia $(0.5 \mathrm{~mm})$ (Silver and Erecińska, 1994), and this decreased the number of ins $2 \mathrm{mRNA}$ molecules in single neurogliaform cells to $14 \pm 3(n=5, p<0.008$, KruskalWallis test) and further to $7 \pm 4$ per cell $(n=5, p<0.04)$. In contrast, copy numbers of rps 18 mRNAs coding the homeostatic ribosomal protein S18 (Twigger et al., 2007) were similar in neurogliaform $(n=16,65 \pm 18)$, pyramidal $(n=14,63 \pm 26)$ and fast spiking cells $(n=15,61 \pm 25)$ regardless of external glucose concentrations. In further control experiments, we determined the number of $\operatorname{rps} 18(26 \pm 6)$ and ins $2(1 \pm 0.8)$ mRNAs in glial cells ( $n=5$ and 4 , respectively) showing that our data on mRNA copy numbers exclude DNA contamination which might arise in small cells. The copy number of $\operatorname{rps} 18(p<0.01)$ and ins $2(p<0.04)$ mRNAs in glial cells was less than in either of the three neuron types we tested (Fig. 1C). In addition, we repeated conventional and digital PCRs amplifying both $r p s 18$ and ins 2 without reverse transcriptase reaction and found no amplification and no PCR products meaning that genomic DNA amplification was negligible (Fig. 1C).

An increase in extracellular glucose level might act as a physiological trigger in releasing insulin from neurogliaform cells containing ins 2 mRNAs. To test this hypothesis, we first searched for electrophysiologically measurable effects of external insulin in brain slices and administered insulin in the bath in concentrations (100 nM) taking into account extracellular and intracellular space ratios $(0.18)$ and the $\sim 140 \mu \mathrm{m}$ diffusion into the slice pushing local concentrations down to a few nanomolar at our recording sites (Havrankova et al., 1978a; Nicholson and Syková, 1998). Insulin reversibly decreased the frequency (from $13.0 \pm$ $9.4 \mathrm{~Hz}$ to $7.3 \pm 5.5 \mathrm{~Hz}, n=16, p<0.001$, Wilcoxon test; Fig. $2 A$ ) and amplitude (from $12.1 \pm 8.13 \mathrm{pA}$ to $10.1 \pm 6.28 \mathrm{pA}, n=15$, $p<0.005)$ of spontaneous EPSCs arriving to neocortical neurons in hypoglycemia $(0.5 \mathrm{~mm})$ and application of the specific insulin receptor antagonist S961 (20 nM) (Schäffer et al., 2008) prevented the effect $(12.2 \pm 8.6 \mathrm{~Hz}$ and $12.5 \pm 9.47 \mathrm{pA})$. To test whether neurogliaform cells could mimic the reversible effect of externally added insulin, we performed simultaneous paired recordings in hypoglycemic $(0.5 \mathrm{~mm})$ conditions and puffed hyperglycemic extracellular solution (10 $\mathrm{mm}$ ) locally to the soma of neurogliaform cells while measuring the frequency of spontaneous EPSCs arriving to neighboring neurons (pyramidal cells $(n=5)$, fast spiking basket $(n=4)$, and axo-axonic $(n=1)$ cells, data are pooled as no differences were observed between cell types) (Fig. 2B). Relative to control, the frequency $(9.0 \pm 8.3 \mathrm{~Hz})$ of spontaneous EPSCs decreased after hyperglycemic puffs to neurogliaform cells to $2.4 \pm 1.6 \mathrm{~Hz}(n=10, p<0.004$, Wilcoxon test $)$. When applying S961 before local hyperglycemia on neurogliaform cells, the frequency of spontaneous EPSCs remained unchanged $(8.7 \pm 2.9$ $\mathrm{Hz}$ vs $8.6 \pm 2.2 \mathrm{~Hz}, n=7, p>0.47)$. The effect of glucose puffs to neurogliaform cells was dependent on $\mathrm{Y}$ kinase signaling as shown by experiments in which lavendustin $(5 \mu \mathrm{M})$ intracellularly applied in neighboring pyramidal cells prevented the glucose-induced decrease in sEPSC frequency and amplitude $(6.67 \pm 5.84 \mathrm{~Hz}$ vs $7.12 \pm 5.76 \mathrm{~Hz}, n=5, p=0.78$ and $12.50 \pm$

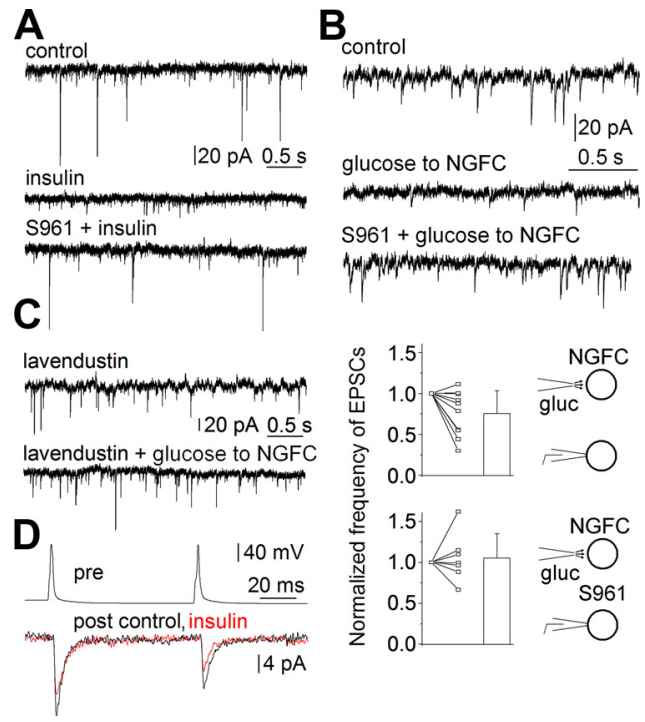

Figure 2. Neurogliaform cells mimic the action of external insulin via insulin receptors. $\boldsymbol{A}$, The frequency of spontaneous EPSCs arriving to neocortical neurons was decreased in response to physiological concentrations of insulin (100 nM), and the specific insulin receptor antagonist S961 (20 nm) reversed the effect. $\boldsymbol{B}$, Mimicking the effect of insulin shown in $\boldsymbol{A}$, local application of hyperglycemic extracellular solution containing $10 \mathrm{~mm}$ glucose (gluc) to neurogliaform cells (NGFCs) identified electrophysiologically and anatomically decreased the frequency of spontaneous EPSCs arriving to neighboring neurons recorded in hypoglycemic $(0.5 \mathrm{~mm})$ conditions and S961 (20 nm) also reversed the effect. Top, Individual experiment. Bottom, Population data. $\boldsymbol{C}$, The effect of hyperglycemic puffs to neurogliaform cells on spontaneous EPSCs in neighboring pyramidal cells was blocked by lavendustin $(5 \mu \mathrm{m})$ intracellularly applied in the pyramidal cells. D, Insulin suppresses the amplitude of unitary EPSCs between layer $2 / 3$ pyramidal cells while leaving the paired pulse ratio unchanged.

$4.45 \mathrm{pA}$ vs $12.92 \pm 3.16 \mathrm{pA}, p=0.44$; Fig. $2 C)$. Paired recordings of layer $2 / 3$ pyramidal cells and postsynaptic pyramidal cells $(n=$ $5)$ and fast spiking basket cells $(n=4)$ showed that insulin decreased the amplitude of unitary EPSCs from $7.18 \pm 5.02$ to $4.61 \pm 3.72 \mathrm{pA}(n=9, p<0.004)$, but the paired pulse ratio remained stationary $(0.82 \pm 0.34$ and $0.84 \pm 0.36$, respectively, $p=0.97$; Fig. $2 D$ ), suggesting a postsynaptic site of action. Thus, local hyperglycemia on neurogliaform cells triggered insulin receptor-mediated responses in the microcircuit mimicking the effect of external insulin.

In a final series of experiments, we addressed mechanisms leading to insulin-like effects of neurogliaform cells. Following previous studies showing that the ATP-sensitive potassium $\left(\mathrm{K}_{\mathrm{ATP}}\right)$ channel blocker glibenclamide promotes both insulin expression and release (Taniguchi et al., 2006), we confirmed the presence of $\mathrm{K}_{\mathrm{ATP}}$ channels in neurogliaform cells using protocols established for cortical interneurons (Zawar et al., 1999). Relative to control conditions having a partially suppressed activity of $\mathrm{K}_{\mathrm{ATP}}$ channels due to hypoglycema $(0.5 \mathrm{~mm})$ in the external solution (Taniguchi et al., 2006), glibenclamide $(20 \mu \mathrm{M})$ in the bath produced a current with current-voltage characteristics of $\mathrm{K}_{\mathrm{ATP}}$ channels in neurogliaform cells $(n=8)$ with a reversal potential $(-96.6 \pm 2.9 \mathrm{mV})$ close to the potassium equilibrium potential (Fig. 3A). In addition, bath-applied glibenclamide $(20 \mu \mathrm{M})$ increased intracellular $\mathrm{Ca}^{2+}$ concentration detected by changes in OGB-1 fluorescence averaged in $50 \mathrm{~s}$ time windows right before and $100-150 \mathrm{~s}$ after application $\left(n=5,1.6 \pm 0.4 \% \Delta \mathrm{F} / \mathrm{F}_{0}, p<\right.$ 0.01 , Wilcoxon test; Fig. $3 B)$. Glibenclamide $(20 \mu \mathrm{M})$ puffs to the soma of neurogliaform cells in hypoglycemia $(0.5 \mathrm{~mm})$ decreased the frequency of spontaneous EPSCs arriving to simultaneously recorded neighboring pyramidal cells $(n=5)$ and fast spiking 
basket cells $(n=5)$ (Fig. $3 C$; from $11.3 \pm$ $7.3 \mathrm{~Hz}$ to $6.1 \pm 5.3 \mathrm{~Hz})$ and $S 961(20 \mathrm{~nm})$ reversed the effect to $9.2 \pm 6.2 \mathrm{~Hz}(n=11$, $p<0.001$, Wilcoxon test; Fig. $3 C$ ). When applying S961 before glibenclamide, the frequency of spontaneous EPSCs remained unchanged $(8.5 \pm 7.8 \mathrm{~Hz}$ vs $9.7 \pm 10.0 \mathrm{~Hz}$, $n=9, p>0.47$; Fig. 3C). Moreover, intracellular application of BAPTA ( $4 \mathrm{~mm})$ in the neurogliaform cells targeted by glibenclamide also prevented changes in the frequency of spontaneous EPSCs $(7.2 \pm 2.6 \mathrm{~Hz}$ vs $6.8 \pm 2.7 \mathrm{~Hz}, n=9, p>$ 0.30; Fig. $3 C$ ), confirming that the effect of glibenclamide was $\mathrm{Ca}^{2+}$ dependent. Neurogliaform cells potentially target $\mathrm{GABA}_{\mathrm{B}}$ receptors (Oláh et al., 2009; Fuentealba et al., 2010), but $\mathrm{GABA}_{\mathrm{B}}$ blockade with CGP35348 $(40 \mu \mathrm{M})$ did not prevent the suppressing effect of glibenclamide on spontaneous EPSC frequencies (10.4 \pm $2.8 \mathrm{~Hz}$ vs $8.5 \pm 3.4 \mathrm{~Hz}, n=5, p<0.01)$. In line with our single-cell digital PCR data showing moderate ins2 RNA expression, we detected no effect on spontaneous EPSC frequencies recorded in nearby pyramidal cells $(n=14)$ or fast spiking basket cells $(n=6)$ when locally puffing glibenclamide to pyramidal cells $(n=11$, $9.5 \pm 4.5 \mathrm{~Hz}$ vs $9.1 \pm 3.8 \mathrm{~Hz}, p=0.76)$ or fast spiking interneurons $(n=9,7.4 \pm 2.8$ $\mathrm{Hz}$ vs $7.1 \pm 2.7 \mathrm{~Hz}, p=0.65$; Fig. $3 C$ ) in hypoglycemia $(0.5 \mathrm{~mm})$. Finally, we added glibenclamide $(20 \mu \mathrm{M})$ to hypoglycemic (0.5 mM) external solution of neocortical brain slices for $30 \mathrm{~min}$ and detected increased insulin levels with radioimmunoassay $(80.8 \pm 17.5 \mathrm{pg} / \mathrm{mg}$ protein, $n=10)$ in slices at the end of treatment compared with controls without glibenclamide (60.4 $\pm 21.7 \mathrm{pg} / \mathrm{mg}$ protein, $n=10, p<$ 0.04, Mann-Whitney test, Fig. 3D). Because glibenclamide could not trigger insulin receptor-mediated effects around pyramidal and fast spiking cells, a fraction of this insulin, locally synthesized in acute brain slices in response to glibenclamide, could be produced by neurogliaform interneurons. Moreover, slices incubated in ACSF containing 2.4 or $10 \mathrm{~mm}$ glucose showed increased insulin content relative to hypoglycemia $(75.4 \pm 14.1$ and $104.2 \pm 26.9$ $\mathrm{pg} / \mathrm{mg}$ protein, $n=10, p<0.05$ and $p<0.01$, respectively) confirming local insulin synthesis.

\section{Discussion}

According to a textbook method for identifying a neurotransmitter, neurogliaform cells mimicked the reversible effect of externally added insulin by releasing a substance we identified as insulin based on the same specific receptor antagonist. It remains to be established how and when peptides in general are being released from interneurons. Neuropeptide release was shown to depend on dendritic $\mathrm{Ca}^{2+}$ entry but does not necessarily require somatic action potentials (Ludwig et al., 2002). Failing to drive insulin release with somatic action potentials suggests that local dendritic electrogenesis, possibly in response to focal excitatory inputs to neu-
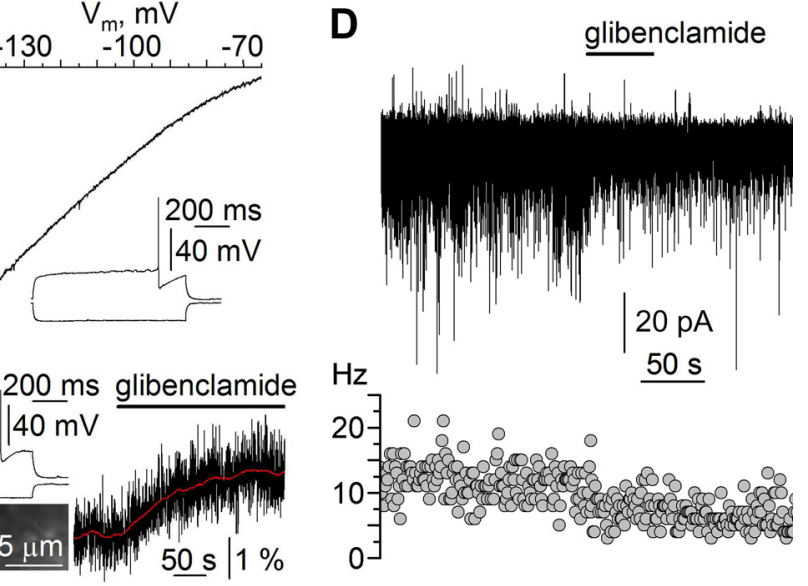

$0^{-}$
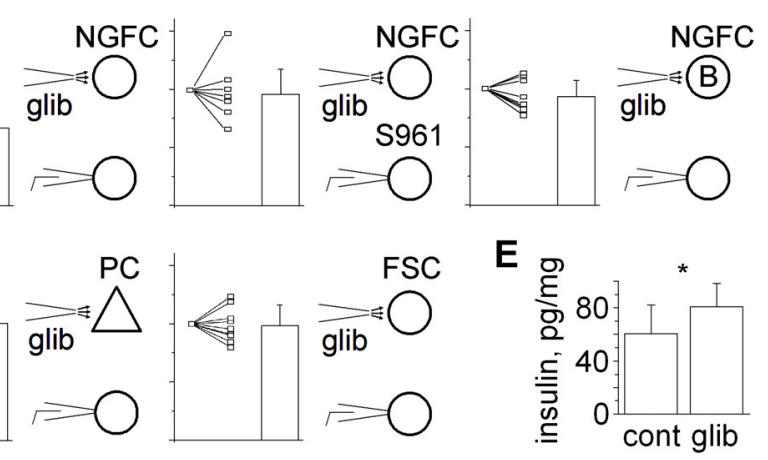

Figure 3. $\mathrm{K}_{\mathrm{ATP}}$ channels and intracellular $\mathrm{Ca}^{2+}$ contribute to insulin receptor-mediated action of neurogliaform cells. $\boldsymbol{A}$, Current-voltage (I-V) relationship of the glibenclamide-sensitive component of currents recorded in a late spiking (inset) neurogliaurogliaform cell identified by its firing pattern (top) responds to bath-applied glibenclamide (20 $\mu \mathrm{m})$ with an increase of the to neurogliaform cells (NGFC) significantly decreased the frequency of EPS( in simultaneously monitored neighboring neurons, and this effect was blocked by the insulin receptor blocker $\$ 961$ applied extracellularly and also by intracellular application of BAPTA $(\boldsymbol{B})$ in the neurogliaform cell. In contrast, glibenclamide applied to pyramidal cells (PC) and fast spiking cells (FSC) caused no significant changes in the frequency of EPSCs in neighboring neurons. D, Time course of sEPSC amplitude (top) and frequency of neocortical slices showed significantly increased insulin levels relative to hypoglycemia during glibenclamide (glib) application and normoglycemia or hyperglycemia.

rogliaform dendrites, might be required. Action potentials in neurogliaform cells did not decrease sEPSCs during GABA receptor and NPY receptor blockade on the neighboring and synaptically coupled cells (data not shown). However, local variations in glucose levels in physiologically relevant concentrations or targeted glibenclamide application were capable of triggering insulin receptor-mediated action of neurogliaform cells without spikes as glibenclamide (4.2 \pm $1.4 \mathrm{mV}, n=5, p<0.02)$ or glucose $(4.4 \pm 0.6 \mathrm{mV}, n=8, p<0.04)$ depolarized the soma of neurogliaform cells, and these functions required $\mathrm{Ca}^{2+}$ entry. This suggests that $\mathrm{GABAergic}$ cells can contribute to local insulin release in conditions when pancreatic insulin supply temporarily or permanently does not match demand (e.g., the actual extracellular glucose availability).

Insulin regulates the metabolism, molecular composition, and cognitive performance of microcircuits (Wan et al., 1997; Biessels et al., 1998), and application of external insulin into the CSF was found to decrease food intake (Woods et al., 1979; Porte et al., 2005). Cerebral insulin levels are altered in diabetes, aging, obesity, and Alzheimer's disease (Havrankova et al., 1979; Baskin et al., 1985; Gasparini et al., 2002; Porte et al., 2005; Pilcher, 2006, 
Mehran et al., 2012). A decline in cognitive functions was proven in type II diabetic patients (Elias et al., 1997) and intranasal application of insulin, which does not alter plasma levels but reaches the CSF (Born et al., 2002), was found to be promising in preventing the progression of cognitive impairment (Craft et al., 2012). Thus, potential local sources of insulin might have a modulatory effect on neighboring neural microcircuits in health and disease. Damage to cortical insulin-producing neurons could partially explain lower cerebral levels of the hormone in obesity, aging, and Alzheimer's disease (Havrankova et al., 1979; Gasparini et al., 2002) and potentially contribute to the onset of these conditions. Insulin receptors are abundant in the cerebral cortex (Havrankova et al., 1978a; Porte et al., 2005), but the short halflife might prevent neocortical insulin in reaching relatively distant brain areas known to mediate insulin receptor-dependent processes in energy homeostasis and feeding (Porte et al., 2005). Locally, however, neuronal insulin might fine-tune the passage of glucose through the endothelium of local blood vessels expressing insulin-sensitive glucose transporters (Magistretti et al., 1999; Porte et al., 2005). Neurogliaform cells use an action potential dependent form of GABAergic volume transmission (Oláh et al., 2009), which can interact with insulin in regulating the efficacy of synapses (Wan et al., 1997; Beattie et al., 2000). Insulin recruits additional GABAA receptors to synaptic (Wan et al., 1997) and possibly extrasynaptic membrane compartments of pyramidal neurons shunting excitatory inputs and leading to decreased firing and a reduced frequency of sEPSCs. Neurogliaform cells hyperpolarize the membrane potential of cells expressing GABAergic receptors in their neighborhood, and the insulin receptor-dependent effects of nonspiking neurogliaform cells suggested here might complement the spike-triggered GABAergic actions.

\section{References}

Banks WA, Jaspan JB, Huang W, Kastin AJ (1997) Transport of insulin across the blood-brain barrier: saturability at euglycemic doses of insulin. Peptides 18:1423-1429. CrossRef Medline

Baskin DG, Stein LJ, Ikeda H, Woods SC, Figlewicz DP, Porte D Jr, Greenwood MR, Dorsa DM (1985) Genetically obese Zucker rats have abnormally low brain insulin content. Life Sci 36:627-633. CrossRef Medline

Beattie EC, Carroll RC, Yu X, Morishita W, Yasuda H, von Zastrow M, Malenka RC (2000) Regulation of AMPA receptor endocytosis by a signaling mechanism shared with LTD. Nat Neurosci 3:1291-1300. CrossRef Medline

Biessels GJ, Kamal A, Urban IJ, Spruijt BM, Erkelens DW, Gispen WH (1998) Water maze learning and hippocampal synaptic plasticity in streptozotocin-diabetic rats: effects of insulin treatment. Brain Res 800: 125-135. CrossRef Medline

Born J, Lange T, Kern W, McGregor GP, Bickel U, Fehm HL (2002) Sniffing neuropeptides: a transnasal approach to the human brain. Nat Neurosci 5:514-516. CrossRef Medline

Craft S, Baker LD, Montine TJ, Minoshima S, Watson GS, Claxton A, Arbuckle M, Callaghan M, Tsai E, Plymate SR, Green PS, Leverenz J, Cross D, Gerton B (2012) Intranasal insulin therapy for Alzheimer disease and amnestic mild cognitive impairment: a pilot clinical trial. Arch Neurol 69:29-38. CrossRef Medline

Devaskar SU, Giddings SJ, Rajakumar PA, Carnaghi LR, Menon RK, Zahm DS (1994) Insulin gene expression and insulin synthesis in mammalian neuronal cells. J Biol Chem 269:8445-8454. Medline

Dorn A, Bernstein HG, Rinne A, Ziegler M, Hahn HJ, Ansorge S (1983) Insulin- and glucagonlike peptides in the brain. Anat Rec 207:69-77. CrossRef Medline

Elias PK, Elias MF, D’Agostino RB, Cupples LA, Wilson PW, Silbershatz H, Wolf PA (1997) NIDDM and blood pressure as risk factors for poor cognitive performance: the Framingham Study. Diabetes Care 20:13881395. CrossRef Medline

Faragó N, Kocsis ÁK, Lovas S, Molnár G, Boldog E, Rózsa M, Szemenyei V, Vámos E, Nagy LI, Tamás G, Puskás LG (2013) Digital PCR to deter- mine the number of transcripts from single neurons after patch-clamp recording. BioTechniques 54:327-336. CrossRef Medline

Fuentealba P, Klausberger T, Karayannis T, Suen WY, Huck J, Tomioka R, Rockland K, Capogna M, Studer M, Morales M, Somogyi P (2010) Expression of COUP-TFII nuclear receptor in restricted GABAergic neuronal populations in the adult rat hippocampus. J Neurosci 30:1595-1609. CrossRef Medline

Gasparini L, Netzer WJ, Greengard P, Xu H (2002) Does insulin dysfunction play a role in Alzheimer's disease? Trends Pharmacol Sci 23:288-293. CrossRef Medline

Havrankova J, Roth J, Brownstein M (1978a) Insulin receptors are widely distributed in the central nervous system of the rat. Nature 272:827-829. CrossRef Medline

Havrankova J, Schmechel D, Roth J, Brownstein M (1978b) Identification of insulin in rat brain. Proc Natl Acad Sci U S A 75:5737-5741. CrossRef Medline

Havrankova J, Roth J, Brownstein MJ (1979) Concentrations of insulin and insulin receptors in the brain are independent of peripheral insulin levels: studies of obese and streptozotocin-treated rodents. J Clin Invest 64:636642. CrossRef Medline

Kuwabara T, Kagalwala MN, Onuma Y, Ito Y, Warashina M, Terashima K, Sanosaka T, Nakashima K, Gage FH, Asashima M (2011) Insulin biosynthesis in neuronal progenitors derived from adult hippocampus and the olfactory bulb. EMBO Mol Med 3:742-754. CrossRef Medline

Ludwig M, Sabatier N, Bull PM, Landgraf R, Dayanithi G, Leng G (2002) Intracellular calcium stores regulate activity-dependent neuropeptide release from dendrites. Nature 418:85-89. CrossRef Medline

Magistretti PJ, Pellerin L, Rothman DL, Shulman RG (1999) Energy on demand. Science 283:496-497. CrossRef Medline

Margolis RU, Altszuler N (1967) Insulin in the cerebrospinal fluid. Nature 215:1375-1376. CrossRef Medline

Mehran AE, Templeman NM, Brigidi GS, Lim GE, Chu KY, Hu X, Botezelli JD, Asadi A, Hoffman BG, Kieffer TJ, Bamji SX, Clee SM, Johnson JD (2012) Hyperinsulinemia drives diet-induced obesity independently of brain insulin production. Cell Metab 16:723-737. CrossRef Medline

Nicholson C, Syková E (1998) Extracellular space structure revealed by diffusion analysis. Trends Neurosci 21:207-215. CrossRef Medline

Oláh S, Füle M, Komlósi G, Varga C, Báldi R, Barzó P, Tamás G (2009) Regulation of cortical microcircuits by unitary GABA-mediated volume transmission. Nature 461:1278-1281. CrossRef Medline

Pilcher H (2006) Alzheimer's disease could be "type 3 diabetes." Lancet Neurol 5:388-389. CrossRef Medline

Porte D Jr, Baskin DG, Schwartz MW (2005) Insulin signaling in the central nervous system: a critical role in metabolic homeostasis and disease from C. elegans to humans. Diabetes 54:1264-1276. CrossRef Medline

Schäffer L, Brand CL, Hansen BF, Ribel U, Shaw AC, Slaaby R, Sturis J (2008) A novel high-affinity peptide antagonist to the insulin receptor. Biochem Biophys Res Commun 376:380-383. CrossRef Medline

Silver IA, Erecińska M (1994) Extracellular glucose concentration in mammalian brain: continuous monitoring of changes during increased neuronal activity and upon limitation in oxygen supply in normo-, hypo-, and hyperglycemic animals. J Neurosci 14:5068-5076. Medline

Taniguchi CM, Emanuelli B, Kahn CR (2006) Critical nodes in signalling pathways: insights into insulin action. Nat Rev Mol Cell Biol 7:85-96. CrossRef Medline

Twigger SN, Shimoyama M, Bromberg S, Kwitek AE, Jacob HJ (2007) The Rat Genome Database, update 2007: easing the path from disease to data and back again. Nucleic Acids Res 35:D658-D662. CrossRef Medline

Wan Q, Xiong ZG, Man HY, Ackerley CA, Braunton J, Lu WY, Becker LE, MacDonald JF, Wang YT (1997) Recruitment of functional GABA(A) receptors to postsynaptic domains by insulin. Nature 388:686-690. CrossRef Medline

Woods SC, Porte D Jr (1977) Relationship between plasma and cerebrospinal fluid insulin levels of dogs. Am J Physiol 233:E331-E334. Medline

Woods SC, Lotter EC, McKay LD, Porte D Jr (1979) Chronic intracerebroventricular infusion of insulin reduces food intake and body weight of baboons. Nature 282:503-505. CrossRef Medline

Zawar C, Plant TD, Schirra C, Konnerth A, Neumcke B (1999) Cell-type specific expression of ATP-sensitive potassium channels in the rat hippocampus. J Physiol 514:327-341. CrossRef Medline 